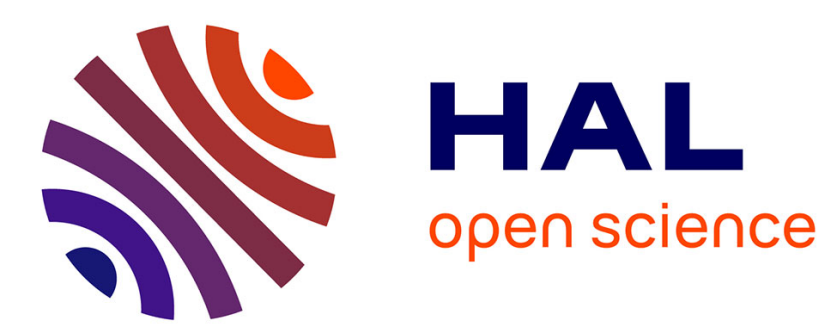

\title{
Mineralogical and physico-chemical characterizations of clay from Keur Saër (Senegal)
}

\author{
A. Mbaye, C. A. K. Diop, Benaïssa Rhouta, J. M. Brendle, François Senocq, \\ Francis Maury, D. P. Diallo
}

\section{- To cite this version:}

A. Mbaye, C. A. K. Diop, Benaïssa Rhouta, J. M. Brendle, François Senocq, et al.. Mineralogical and physico-chemical characterizations of clay from Keur Saër (Senegal). Clay Minerals, 2012, vol. 47 ( ${ }^{\circ}$ 4), pp. 499-511. 10.1180/claymin.2012.047.4.08 . hal-01166759

\section{HAL Id: hal-01166759 \\ https://hal.science/hal-01166759}

Submitted on 23 Jun 2015

HAL is a multi-disciplinary open access archive for the deposit and dissemination of scientific research documents, whether they are published or not. The documents may come from teaching and research institutions in France or abroad, or from public or private research centers.
L'archive ouverte pluridisciplinaire HAL, est destinée au dépôt et à la diffusion de documents scientifiques de niveau recherche, publiés ou non, émanant des établissements d'enseignement et de recherche français ou étrangers, des laboratoires publics ou privés. 


\section{OATAO \\ Open Archive Toulouse Archive Ouverte}

\section{Open Archive TOULOUSE Archive Ouverte (OATAO)}

OATAO is an open access repository that collects the work of Toulouse researchers and makes it freely available over the web where possible.

This is an author-deposited version published in : http://oatao.univ-toulouse.fr/ Eprints ID : 14094

To link to this article : doi: 10.1180/claymin.2012.047.4.08

URL : http://dx.doi.org/10.1180/claymin.2012.047.4.08

To cite this version : Mbaye, A. and Diop, C. A. K. and Rhouta, Benaïssa and Brendle, J. M. and Senocq, François and Maury, Francis and Diallo, D. P. Mineralogical and physico-chemical characterizations of clay from Keur Saër (Senegal). (2012) Clay Minerals, vol. 47 ( $\mathrm{n}^{\circ}$ 4). pp. 499-511. ISSN 0009-8558

Any correspondance concerning this service should be sent to the repository administrator: staff-oatao@ listes-diff.inp-toulouse.fr 


\title{
Mineralogical and physico-chemical characterizations of clay from Keur Saër (Senegal)
}

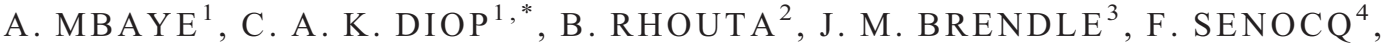 \\ F. MAURY ${ }^{4}$ AND D. P. DIALLO ${ }^{5}$ \\ ${ }^{1}$ Laboratoire de Chimie Minérale et Analytique, Faculté des Sciences et Techniques - Université Cheikh Anta Diop, \\ Dakar, Sénégal, ${ }^{2}$ Laboratoire de Matière Condensée et Nanostructures (LMCN), Faculté des Sciences et Techniques \\ Gueliz, BP 549, Université Cadi Ayyad Marrakech, M orocco, ${ }^{3}$ Equipe Matériaux à Porosité Contrôlée, Institut de \\ Science des Matériaux de Mulhouse (IS2M) LRC CNRS 7228, Université de Haute Alsace, Institut Jean-Baptiste \\ Donnet, 3 b rue Alfred Werner, 68093 Mulhouse cedex, France, ${ }^{4}$ CIRIMAT, CNRS-UPS-INP, ENSIACET, 4 allée \\ Emile Monso, BP 44362, 31030, Toulouse, France, and ${ }^{5}$ Département de géologie, Faculté des Sciences et Techniques \\ - Université Cheikh Anta Diop, Dakar, Sénégal
}

\begin{abstract}
There is interest in exploiting and developing natural resources, particularly deposits of natural clays. Senegal has several clay mineral deposits for which chemical and mineralogical compositions have been little studied. Some of these natural materials are nowadays used in pottery and ceramics. To extend applications, a better basic knowledge is required and, for this objective, the raw clay and separated $<2 \mu \mathrm{m}$ clay fraction from Keur Saër (Senegal) were subjected to chemical and mineralogical studies. Several techniques including X-ray diffraction (XRD), thermal analysis (TG-DTA), Fourier transform infrared spectroscopy (FTIR), scanning electron microscopy (SEM), $\mathrm{N}_{2}$ adsorption-desorption isotherms, cation exchange capacity (CEC) measurements and solid state nuclear magnetic resonance (NMR) have been used to characterize the material. It was found that the raw clay and the separated clay fraction consist of a mineral mixture in which kaolinite is the main component. ${ }^{29} \mathrm{Si}$ and ${ }^{27} \mathrm{Al}$ MAS-NMR spectra show the presence of silicon atoms linked to three other silicon atoms via oxygen atom and six coordinated Al atoms. Significant increases in the specific surface area and cation exchange capacity were observed on purification, reaching a maximum of about $73.2 \mathrm{~m}^{2} \mathrm{~g}^{-1}$ and $9.5 \mathrm{meq} / 100 \mathrm{~g}$ for the separated fine clay fraction while the values for the raw material were around $28.9 \mathrm{~m}^{2} \mathrm{~g}^{-1}$ and $7.3 \mathrm{meq} / 100 \mathrm{~g}$.
\end{abstract}

KEYWORDS: specific surface area, cation exchange capacity, spectroscopic and chemical analysis, kaolinite, clay minerals, Keur Saër, Senegal.

Clays are used as raw materials in many application fields such as bulk ceramics (Moussi et al., 2011; Wyszomirski \& Galos, 2009; Pialy et al., 2008), clarification of various effluents (Ribeiro et al., 2008; Bouna et al., 2010), catalysis (Marcos \&

\footnotetext{
*E-mail: cakdiop@hotmail.com
}

Rosa, 1995; Zheng et al., 2010), photocatalysis (Bouna et al., 2011) and therapeutics (Rebelo et al., 2010). These applications are strongly dependent on the clay's structure, chemical composition and physical properties (Grim, 1960). The knowledge of these characteristics should allow better use and possibly may open new application techniques. This provides the reason for a basic research program we are working on that deals with the mineralogical and physicochemical characterization of natural 
clays of different origins (Rhouta et al., 2008; Bouna et al., 2011).

Kaolin is used in agriculture for the protection of crops as a carrier and diluent in fertilizers, pesticides and related products. The natural clay studied here is locally and traditionally used in the manufacture of pottery and clay vessels. In most part of African rural areas, clay vessels are mainly used for household water treatment and safe storage. Other new domestic applications such as cooking stoves have appeared; other applications have arisen in response to problems such as deforestation, erosion, energy waste and health associated with the tree stone wood fires, traditionally used for cooking in rural areas. Clay is also one of the most common building materials. However, in rural areas worldwide and especially in Senegal, it is replaced by cement, which is more expensive, even if clay deposits are abundant, because of the rapid deterioration of clay buildings. The same degradation problem has also been noticed in the pottery and vessels made with clay. A consequence of this is a progressive disappearance of clay brick factories in Senegal. On the other hand, clay-made edifices hundreds of years old still exist in Africa and in the wider world, e.g. the mosque in Toumbouctou (Mali) or in the city of Bam (Iran). A knowledge of clay mineral properties is fundamental for sustainable construction and development in Senegal and more generally in emerging countries.

The aim of this work is to characterize the raw clay from Keur Saër (central Senegal) and its fine separate fraction in order to enhance and extend its applications, which are limited at the present time to the fabrication of traditional products, such as earthen pots, rustic utensils and ornamental objects. It should be noted that only a few data are reported in the literature devoted to the mineralogical and physicochemical characterization of these clay materials. The raw sample and its separated clay fraction were studied by several techniques to obtain accurate information on their chemical composition, structure and basic physical properties such as adsorption-desorption behaviour and cation exchange capacity. This should help determine the best uses that can be made of the material. Beside kaolinite, the samples contain iron oxides and hydroxides and other less representative oxides. An attempt was made to reduce the percentage of iron in the samples and the results for the purified material are also reported.

\section{GEOLOGICAL SETTING AND CONTEXT}

The first studies dealing with the geology of Senegal began in 1898 (Meunier, 1898, 1904). Later, the work of several other researchers (Roques \& Nickles, 1946; Tessier, 1946, 1949) elucidated the geological history of the Gulf of Senegal. The Senegalo-Mauritanian Basin, which covers almost all the Senegalese territory, lays on the West African Craton and is $1300 \mathrm{~km}$ long (Fig. 1). It occupies the central part of the Northwest African Coastal Basin, and extends from the Reguibat ridge (Mauritania) to the north end of the Guinean fault. It is a typical passive margin, opening westward to the Atlantic Ocean, and whose eastern limit is represented by the Pan African-Mauritanides orogenic chains. The southern margin of the basin partially covers the Palaeozoic Bove basin (Ritz \& Bellion, 1988). The Cenozoic formation outcrops are limited to the cliffs of the peninsula of Cap Verde and that of Thies. Those of the MesoCenozoic series correspond to the Campanian and Maastrichtian formations. From the litostratigraphic point of view, the area involved in the present study is occupied by the inferior to medium Lutetian represented by the middle Eocene age formation of Lam-Lam, which consists of alternative marl discocyclinas and calcareous macrofossils. The Tertiary formations contain significant resources of phosphates, limestone, attapulgites and clays in the Eocene formation. The area of Keur Saër where the samples for this study were collected lies between $14^{\circ} 40^{\prime} 0$ north and $16^{\circ} 23^{\prime} 0$ west. It is located in the region of Diourbel (Fig. 1b) in the central part of Senegal, and this geological formation corresponds to the middle Eocene (Fig. 1a). The clay samples were collected from deposits exploited by traditional potters and brick makers, the locality being very rich in clay minerals (Fig. 1c); however, no scientific characterization has been undertaken to ascertain if these clay materials are best suited for this purpose and, according to their characteristics, if other applications could be developed.

\section{EXPERIMENTAL}

\section{Clay purification}

The raw clay samples (namely $\operatorname{argB}$ ) were saturated with sodium by slowly mixing and stirring 

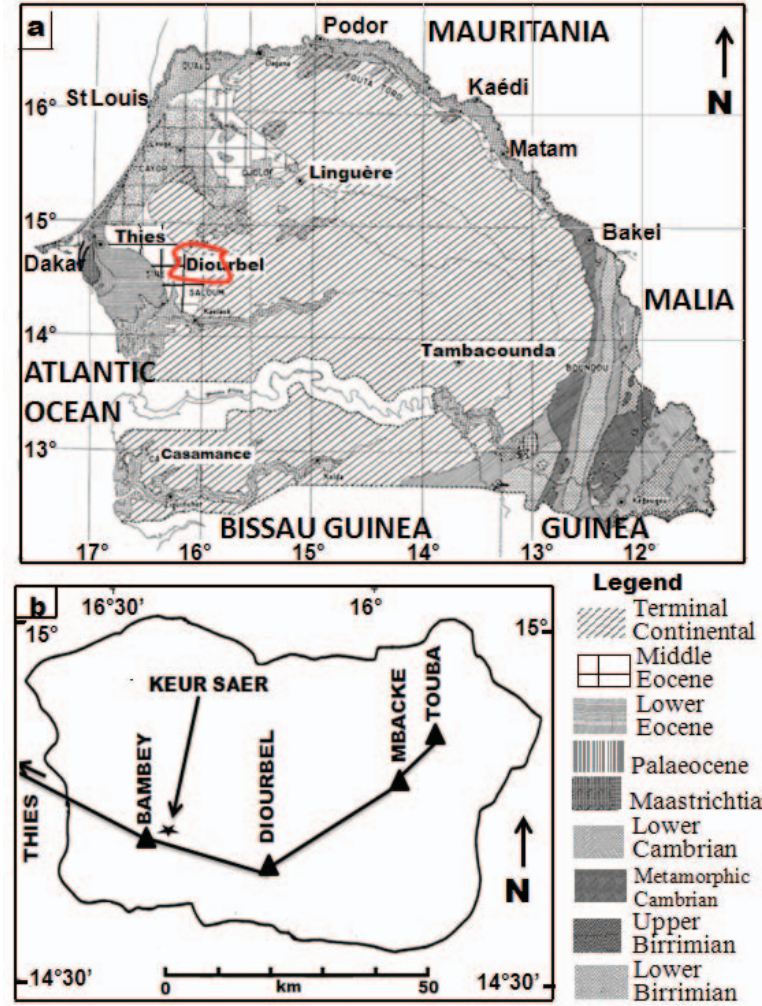

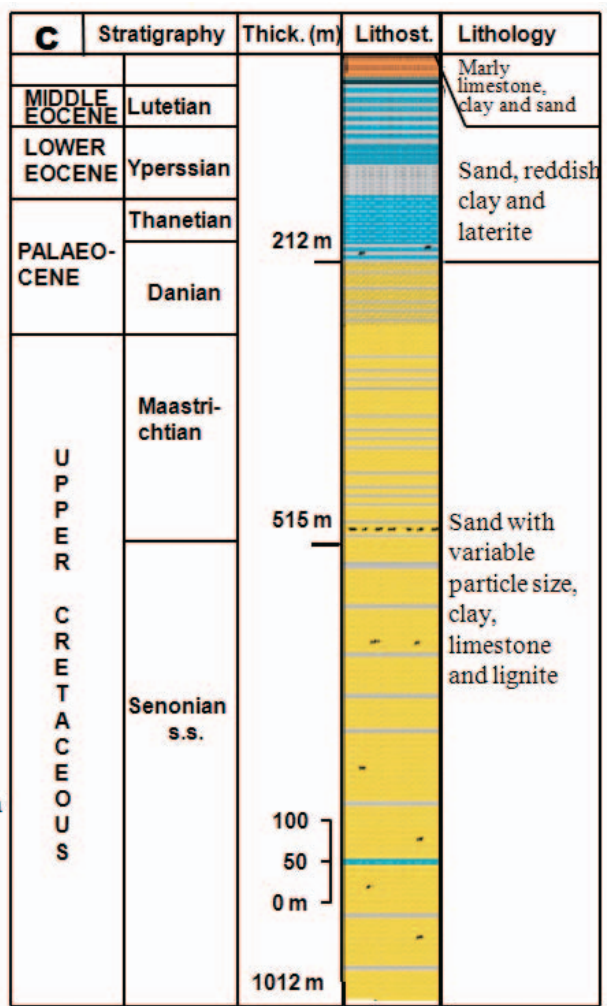

Fig. 1. (a) Simplified geological map of Senegal showing the different geological formations (Brigand, 1960); (b) the region of Diourbel (where Keur Saër area is located); and (c) the stratigraphical and lithostigraphical log of the region of Diourbel (Barrusseau et al., 2009).

$30 \mathrm{~g}$ of raw clay powder with $200 \mathrm{ml}$ of $\mathrm{NaCl}$ aqueous solution $(1 \mathrm{~m})$. Thereafter, the supernatant was discarded after the mixture settled and the $\mathrm{NaCl}$ solution was renewed. The operation was repeated three times to ensure a complete ion exchange between the sodium of the $\mathrm{NaCl}$ solution and ions of the clay in order to render the clay homoionic. The $\mathrm{Na}^{+}$-saturated clay was then washed several times with distilled water to remove the $\mathrm{NaCl}$ salt excess, as evidenced by the $\mathrm{AgNO}_{3}$ test, and to enhance the stability of the clay dispersion. After $\mathrm{Na}^{+}$homoionization, the fine clay fraction $(<2 \mu \mathrm{m})$ was extracted using standard sedimentation procedures (Holtzapfell, 1985) and dried at $80^{\circ} \mathrm{C}$ : this sample is labelled $\operatorname{argF} 1$. The fine fraction homoionized with $\mathrm{Na}^{+}$was further treated with oxalic acid solution $(20 \%$ in water) at $60^{\circ} \mathrm{C}$ for $6 \mathrm{~h}$ to reduce selectively associated free iron phases: this sample is named $\operatorname{argF} 2$.

\section{Characterization}

The identification of the crystalline phases was carried out by X-ray diffraction (XRD), using a Bruker D8 Advance diffractomer using Ni filtered $\mathrm{Cu}-k \alpha$ radiation $(1.5418 \AA)$ in Bragg-Bretano geometry. A LEO435VP scanning electron microscopy (SEM) equipped with an X-ray energy dispersion spectrometer (EDS) was used to characterize clay particle morphology and to perform local elemental analysis. The specific surface area of the samples, the specific pore volume and the average pore diameter were measured by using a Micromeritics ASAP $2010 \mathrm{~V} 5.02 \mathrm{H}$ system. The surface areas were obtained by using the BrunauerEmmet-Teller (BET) equation. The BET analysis (Brunauer et al., 1938) was carried out using nitrogen adsorption-desorption isotherms at $77 \mathrm{~K}$. The samples were outgassed prior to measurement 
by heat treatment at $300^{\circ} \mathrm{C}$ for two hours. Pore size distributions were derived from desorption isotherms using the Barret-Joyner-Halenda (BJH) method. The cationic exchange capacity (CEC) of the samples was determined using the cobalt hexammonium complex method (Mantin \& Glaeser, 1960). The chemical compositions of the clay samples were determined by inductively coupled plasma-optical emission spectrometry using an ICP-OES Iris Advantage instrument equipped with a Thermo Scientific radially viewed torch. The Fourier-Transform infrared spectra (FTIR) were recorded from $\mathrm{KBr}$ pellets using a FT-IR 5700 Nicolet spectrophotometer. The range of frequencies was $4000-400 \mathrm{~cm}^{-1}$. Solid-state ${ }^{27} \mathrm{Al}$ and ${ }^{29} \mathrm{Si}$ magic angle spinning (MAS) NMR spectra were obtained at room temperature $\left(21^{\circ} \mathrm{C}\right)$ on a Bruker Advance $400(9.4 \mathrm{~T})$ spectrometer equipped with a $4 \mathrm{~mm}$ probe (zirconia rotors). The ${ }^{29} \mathrm{Si}$ and ${ }^{27} \mathrm{Al}$ spectra were referenced to the external standards tetramethylsilane and $\left[\mathrm{Al}\left(\mathrm{H}_{2} \mathrm{O}\right)_{6}\right]^{3+}$ respectively. ${ }^{27} \mathrm{Al}$ spectra $(104.12 \mathrm{MHz})$ were recorded with MAS at a speed of $8 \mathrm{kHz}\left(20^{\circ}\right)$ and a recycle delay of $3 \mathrm{~s}$. ${ }^{29} \mathrm{Si}$ spectra $(79.39 \mathrm{MHz})$ were recorded at a speed of $8 \mathrm{kHz}\left(30^{\circ}\right)$ and a recycle delay of $60 \mathrm{~s}$. For the 1D ${ }^{27} \mathrm{Al}$ and ${ }^{29} \mathrm{Si}$ experiments ${ }^{1} \mathrm{H}$ SPINAL-64 $\left(\gamma \mathrm{B}_{1} / 2 \pi=83.3 \mathrm{kHz}\right)$ decoupling was applied during the acquisition period. Thermal analyses (TG-DTA) were carried out using a Setaram apparatus operating at a heating rate of $10^{\circ} \mathrm{C}$ $\min ^{-1}$ under air with an ambient temperature of $1400^{\circ} \mathrm{C}$. All characterizations were performed in the CIRIMAT, except NMR analyses (Lab. de Chimie de Coordination, Toulouse, France), ICP-OES analyses (Service d'Analyse des Roches et Minéraux, Vandoeuvre les Nancy, France) and CEC determination (Lab. de Chimie Minérale et Analytique, Dakar).

\section{RESULTS AND DISCUSSION}

\section{Structural analysis}

Microstructural characterization. The SEM images and EDS analyses of the raw clay ( $\operatorname{argB})$ and the treated separated fine fraction $(\operatorname{argF} 2)$ are shown in Figs 2 and 3 respectively. The SEM images of the raw samples reveal large aggregates (typically several tens of micrometres wide) consisting of pseudo-hexagonal micrometre-sized platelets partially coated with sub-micrometric particles (Fig. 2a). This microstructure, consisting of randomly oriented platelets, resembles that of kaolinite. As a representative analysis, the EDS spectrum of the same area shows the presence of $\mathrm{Si}$ and $\mathrm{Al}$ as the main cations and $\mathrm{Ti}, \mathrm{Fe}, \mathrm{Ca}$ and $\mathrm{Mg}$ as minor elements (Fig. 3a). The intense $\mathrm{Si}$ peak could be ascribed to both clay minerals and possibly free silica. Titanium probably corresponds to titania impurity while $\mathrm{Ca}$ and $\mathrm{Mg}$ are due probably to carbonates such as dolomite and/or calcite.

The particles of the separated fine fraction $(\operatorname{argF} 2)$ are still in the form of platelets but appear more irregular in comparison to the raw clay as a result of the purification. The platelets are still present and also agglomerate to form micro-
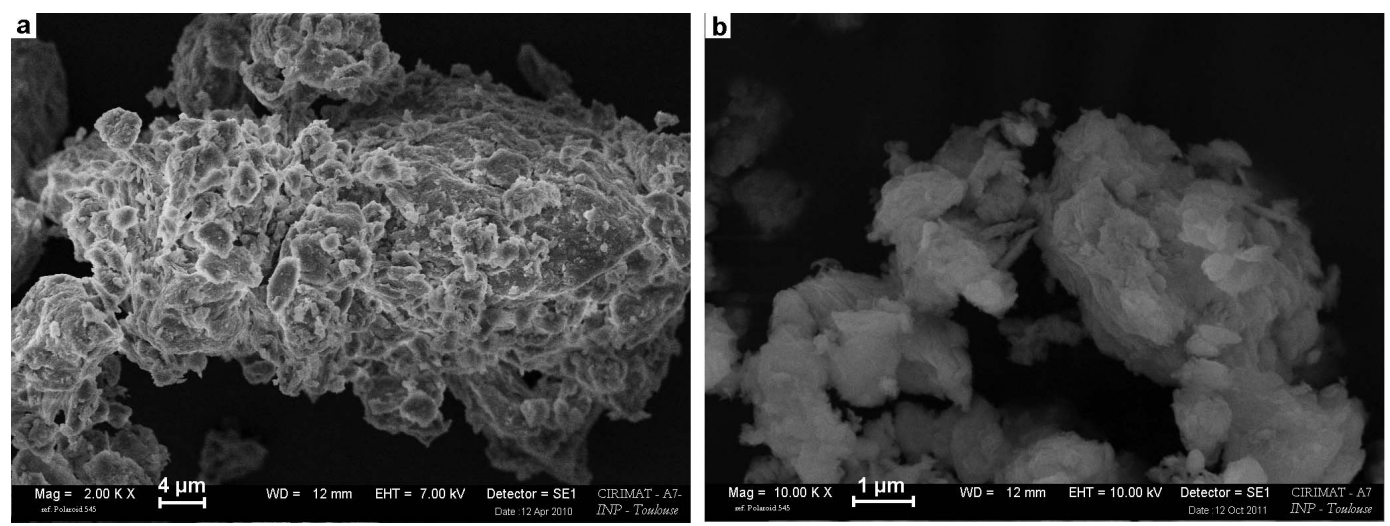

FIG. 2. SEM micrographs of the raw clay sample $\operatorname{argB}$ (a) and the oxalic acid treated $\mathrm{Na}^{+}$-homoionized fine fraction $\operatorname{argF} 2(b)$. 


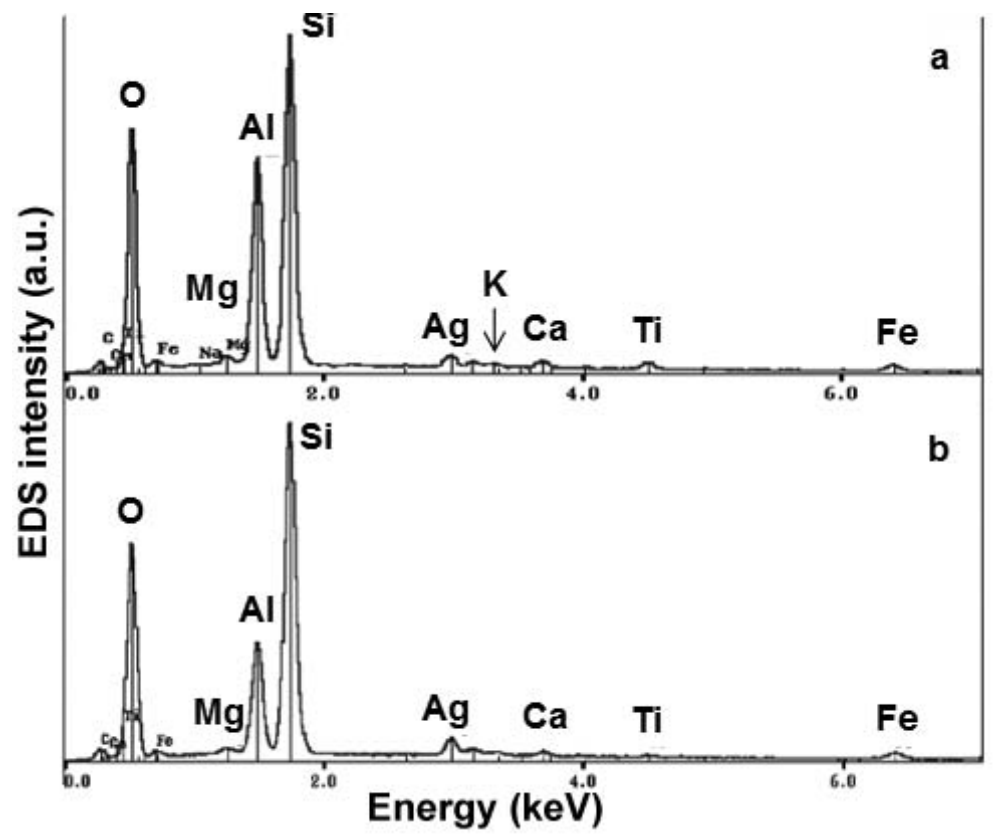

FIG. 3. EDS analysis of the raw clay $\operatorname{argB}$ (a) and the purified $\operatorname{argF} 2$ sample (b). The silver detected at $3 \mathrm{kV}$ originates from the conductive adhesive used to fix the powder on the sample holder.

metric grains but they are clearly less contaminated by small sub-micrometric particles (Fig. 2b). Furthermore they are partially exfoliated. The EDS analysis of the area corresponding to the SEM image in Fig. $2 b$ reveals that the elements mentioned above still exist in the purified clay fraction (Fig. 3b) but with a relatively lower content indicated by a decrease in the EDS intensity ratio $M / \mathrm{Si}(M=\mathrm{Al}, \mathrm{Ti}, \mathrm{Ca}, \mathrm{Mg})$. This indicates they were not completely removed by purification.

Identification of crystalline phases. The XRD patterns were recorded at each step of the sample preparation. The results are presented in Fig. 4a for the raw clay sample $(\operatorname{argB})$ and the oxalic acid treated $\mathrm{Na}^{+}$-saturated fine fraction $(\operatorname{argF} 2)$ as well as after further treatment following saturation with ethylene glycol (argF2-g) and annealing at $490^{\circ} \mathrm{C}$ in air $\left(\operatorname{argF} 2-490^{\circ} \mathrm{C}\right)$. The treatment with ethylene glycol and the annealing in air were performed in order to clearly identify the $7 \AA$ phase. In the raw clay sample very intense reflections due to quartz (Q), which appears to be the most abundant diluting mineral, were observed at $2 \theta=20.8^{\circ}(4.2 \AA), 26.6^{\circ}$ $(3.3 \AA), 36.5^{\circ}(2.4 \AA), 39.7^{\circ}(2.2 \AA), 40.0^{\circ}(2.2 \AA)$, $42.5^{\circ}(2.1 \AA), 46.0^{\circ}(1.9 \AA), 50.1^{\circ}(1.8 \AA), 54.8^{\circ}$ $(1.6 \AA)$ and $55.3^{\circ}(1.5 \AA)$. The reflections observed at $2 \theta$ around $12.4^{\circ}(7.3 \AA), 24.9^{\circ}(3.5 \AA)$ and $38.7^{\circ}$ $(2.3 \AA)$ indicate the presence of a second phase, named $7 \AA$ phase, at this stage of the study. The basal reflection of kaolinite in $\mathrm{Na}^{+}$-saturated clay fraction diffractograms was intensified while the peak position remained unchanged following the specific treatments (Fig. 4a). Indeed, the ethylene glycol treatment (argF2-g) did not lead to significant changes in the clay fraction diffractogram. The XRD pattern of the fine fraction sample heated at $490^{\circ} \mathrm{C}$ in air $\left(\operatorname{argF} 2-490^{\circ} \mathrm{C}\right)$ indicates the disappearance of the peaks at $12.4^{\circ}(7.3 \AA), 24.9^{\circ}$ $(3.5 \AA)$ and $35^{\circ}(2.5 \AA)$, confirming that the $7 \AA$ phase corresponds to kaolinite (Holtzapfell, 1985). After homoionization with $\mathrm{Na}^{+}$and extraction of the $<2 \mu \mathrm{m}$ clay fraction the XRD pattern shows that peak intensities of quartz significantly decrease while the reflections corresponding to clay minerals appear more intense. This indicates a reduction of the amount of quartz in the purified sample but the purification procedure was not sufficiently efficient to remove it completely. Nevertheless, the presence of minor 2:1 phases or other impurities cannot be definitely ruled out, even if the XRD pattern of an oriented preparation (Fig. 4b) did not show their presence. It has been reported that small amounts of 

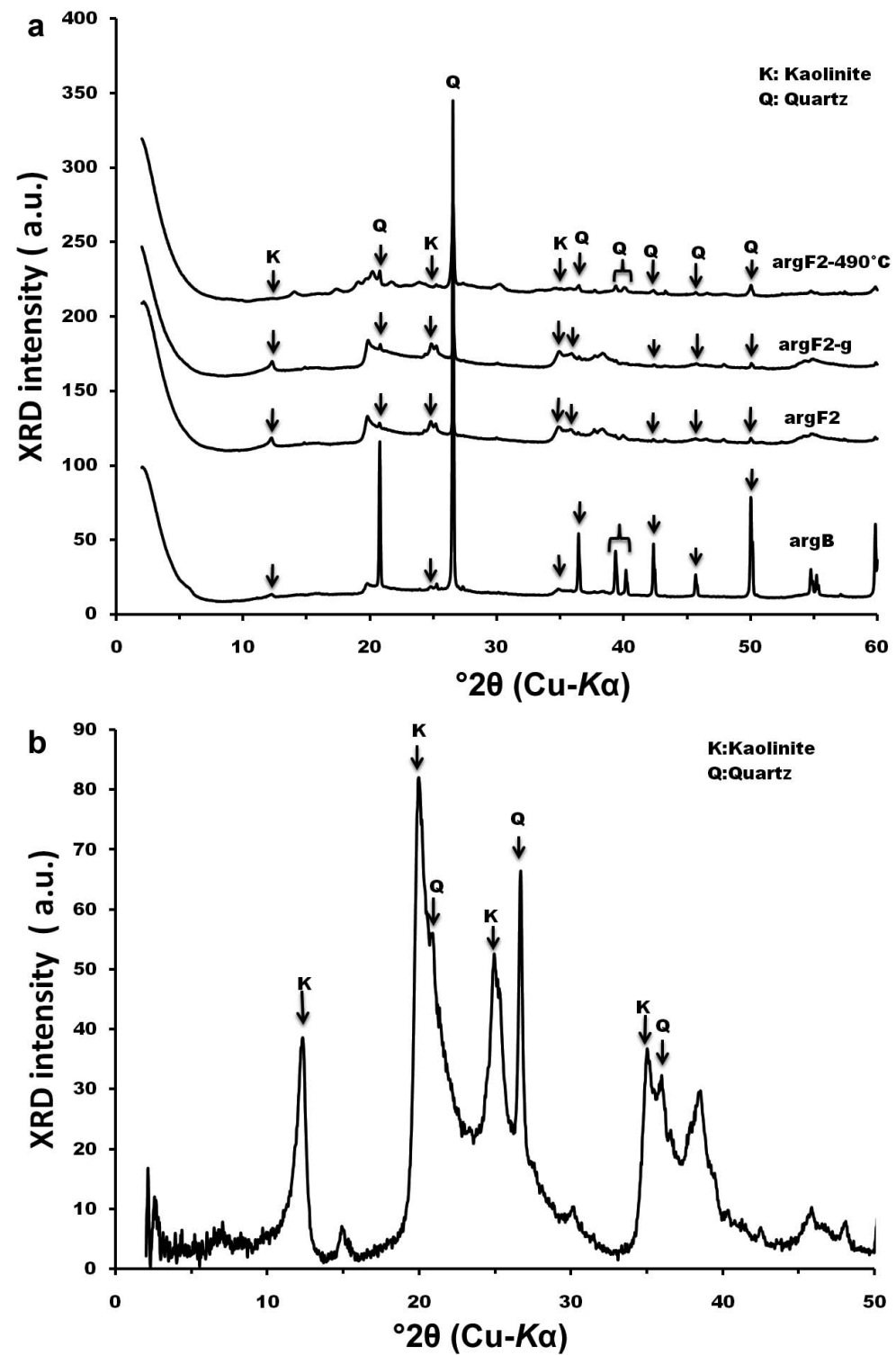

FIG. 4. XRD patterns of (a) randomly oriented preparations including the raw clay ( $\operatorname{argB}$ ) and the treated samples $\left(\operatorname{argF} 2, \operatorname{argF} 2-\mathrm{g}, \operatorname{argF} 2-490^{\circ} \mathrm{C}\right)$ and (b) an oriented preparation of the oxalic acid treated sample $\operatorname{argF} 2$.

expandable 2:1 layers $(<5 \%)$ may escape detection by XRD analysis if they are interstratified with kaolinite as the principal mineral (Lim et al., 1980). The presence of these impurities is therefore revealed by chemical properties (see Tables 1 and 2). Furthermore, any peak related to either titania or carbonate impurities is likely to be due to poor crystallinity or to their presence in small amounts, lower than the detection threshold of XRD analysis
$(<5 \%)$. This is in good agreement with the EDS analysis.

\section{Elemental analysis}

The chemical composition of the raw clay $(\operatorname{argB})$, the $\mathrm{Na}^{+}$- homoionized fine clay fraction $(\operatorname{argF} 1)$ and the oxalic acid treated clay fraction $(\operatorname{argF} 2)$ are reported in Table 1. The results reveal that the raw 
TABLE 1. Chemical analysis of the clay samples determined by ICP-OES (wt.\%). LOI $=$ loss on ignition.Clay

\begin{tabular}{lcccccccccccr}
\hline Sample & $\mathrm{SiO}_{2}$ & $\mathrm{Al}_{2} \mathrm{O}_{3}$ & $\mathrm{Fe}_{2} \mathrm{O}_{3}$ & $\mathrm{MnO}$ & $\mathrm{MgO}$ & $\mathrm{CaO}$ & $\mathrm{Na}_{2} \mathrm{O}$ & $\mathrm{K}_{2} \mathrm{O}$ & $\mathrm{TiO}_{2}$ & $\mathrm{P}_{2} \mathrm{O}_{5}$ & LOI & Total \\
\hline $\operatorname{argB}$ & 77.54 & 8.82 & 3.30 & 0.03 & 0.35 & 0.49 & 0.06 & 0.24 & 0.57 & 0.13 & 8.19 & 99.71 \\
$\operatorname{argF1}$ & 44.04 & 23.66 & 7.26 & 0.07 & 0.81 & 0.31 & 1.57 & 0.49 & 1.62 & 0.30 & 19.40 & 99.52 \\
$\operatorname{argF2}$ & 46.87 & 24.61 & 4.62 & 0.02 & 0.85 & 1.06 & 0.06 & 0.38 & 1.25 & 0.10 & 20.60 & 100.42
\end{tabular}

clay is essentially constituted of $\mathrm{Si}$ and $\mathrm{Al}$ oxides. The amount of iron oxide is also noticeable while the contents of alkaline and alkaline-earth oxides are low. The significant iron oxide content explains the light rusty colour of the three clay samples. The fine clay fraction $(\operatorname{argF} 1)$ shows compositions differing from that of the raw clay. The $\mathrm{SiO}_{2}$ content drastically decreases in the $\mathrm{Na}^{+}$-clay separated fraction, probably due to the removal of quartz, in good agreement with the XRD results (Fig. 4). The increase in $\mathrm{Na}_{2} \mathrm{O}$ content accompanied by the presence of $\mathrm{CaO}$ traces indicates that interlayer cations were not completely exchanged with $\mathrm{Na}^{+}$. The noticeable increase of $\mathrm{Al}_{2} \mathrm{O}_{3}$ and $\mathrm{Fe}_{2} \mathrm{O}_{3}$ contents in $\operatorname{argF} 1$ compared with the $\operatorname{argB}$ sample indicates that the clay minerals are more concentrated in the separated clay fraction. The percentage of $\mathrm{Fe}_{2} \mathrm{O}_{3}$ reduces when the fine clay fraction $(\operatorname{argF} 1)$ is treated with oxalic acid $(\operatorname{argF} 2)$; this is as expected since the acid treatment was applied to selectively remove free iron phases. However the percentage of $\mathrm{Al}_{2} \mathrm{O}_{3}$ is still low in comparison with pure kaolinite. The same phenomenon was observed in kaolinite samples from Turkey and Georgia (southeastern USA) and was ascribed, respectively, to a low kaolinization process (Sayin, 2007) and to the presence of non detectible 2:1 mineral phases in the kaolinite (Lim et al., 1980). The former explanation appeard to be more appropriate to our observations. The low $\mathrm{Al}_{2} \mathrm{O}_{3}$ content can also be linked to the silicification of the kaolinite body and isomorphous substitution of $\mathrm{Al}$ in the kaolinite by Fe.

\section{Adsorption properties and exchange capacity}

The adsorption-desorption isotherms of nitrogen do not show significant differences between the raw clay and its separated fine fraction. The typical curves obtained for the raw clay sample $(\operatorname{argB})$ and the oxalic acid treated $\mathrm{Na}^{+}$-separated clay $(\operatorname{argF} 2)$ are given in Fig. 5. The observed isotherms for both samples belong to type IV (especially visible on the desorption branch). However, the rapid increase of the adsorbed quantities close to the origin can be attributed to the presence of micropores. Consequently it is concluded that the isotherms are mixed and belong simultaneously to types IV and I according to the IUPAC classification (Sing et al., 1985). The hysteresis loop shown in Fig. 5 is typical of a mesoporous structure with a contribution from micropores. It is of type $\mathrm{H} 3$, corresponding to wide capillaries having narrow openings and/or the presence of interstices between the parallel plates.

The pore sizes distribution curves given in Fig. 6 indicate a relatively narrow pore size distribution with an average value of $6.4 \mathrm{~nm}$ for $\operatorname{argF} 1$ and $5.0 \mathrm{~nm}$ for argB. The BET equation was applied for the relative pressure range $0.02<p / p_{\mathrm{o}}<0.33$. The adsorption data are summarized in Table 2. The specific surface areas of the raw clay sample and the Na-separated clay fraction are 28.9 and $73.2 \mathrm{~m}^{2} \mathrm{~g}^{-1}$ respectively. According to Lim et al. (1980), these high specific surface area values compared with those of pure kaolinite determined by the BET method, ranging from 10 to $15 \mathrm{~m}^{2} \mathrm{~g}^{-1}$

TABLE 2. Principal physicochemical characteristics of the $\operatorname{argB}$ and $\operatorname{argF} 1$ samples.

\begin{tabular}{lcccc}
\hline Sample & $\begin{array}{c}\text { Specific surface area } \\
\left(\mathrm{m}^{2} \mathrm{~g}^{-1}\right)\end{array}$ & $\begin{array}{c}\text { Average pore } \\
\text { diameter }(\mathrm{nm})\end{array}$ & $\begin{array}{c}\text { Specific pore volume } \\
\left(\mathrm{cm}^{3} \mathrm{~g}^{-1}\right)\end{array}$ & $\begin{array}{c}\text { Cationic exchange } \\
\text { capacity }\left(\mathrm{meq} \mathrm{g}^{-1}\right)\end{array}$ \\
\hline $\operatorname{argB}$ & 28.9 & 5.0 & 0.03 & 7.3 \\
$\operatorname{argF1}$ & 73.2 & 6.4 & 0.11 & 9.5 \\
\hline
\end{tabular}




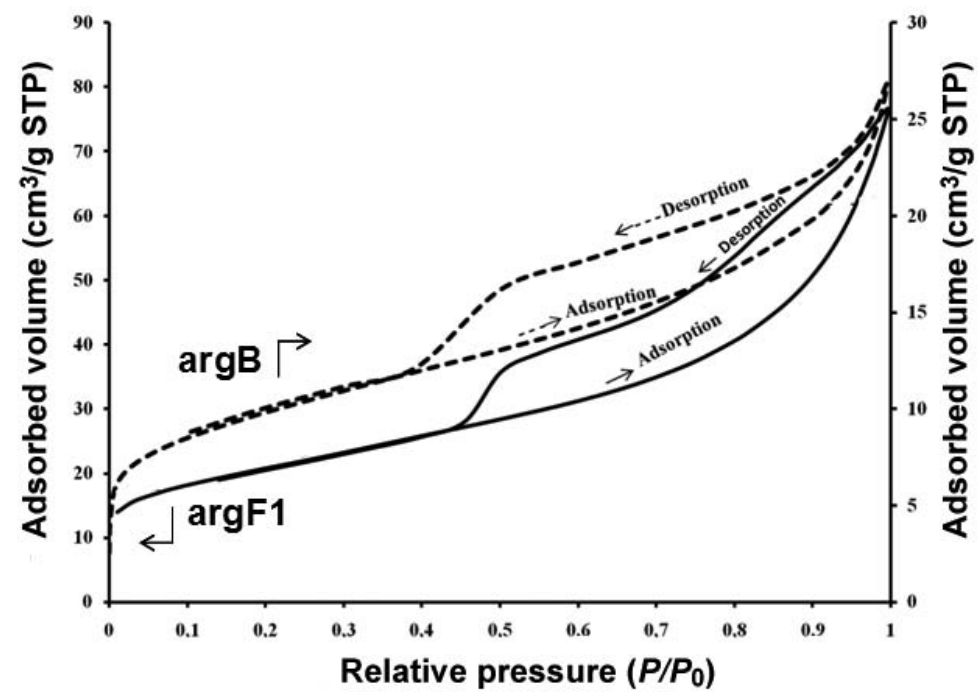

FIG. 5. $\mathrm{N}_{2}$ adsorption-desorption isotherms recorded for the raw clay sample ( $\left.\operatorname{argB}\right)$ and the Na-separated clay $(\operatorname{argF} 1)$.

(Ormsby et al., 1962), can be attributed to the presence of non-detectable 2:1 layers. Small amounts of such materials, which have specific surface values of about $800 \mathrm{~m}^{2} \mathrm{~g}^{-1}$ (Jackson, 1975) in kaolins, significantly increase the net surface area. The specific pore volumes are $0.03 \mathrm{~cm}^{3} \mathrm{~g}^{-1}$ $(\operatorname{argB})$ and $0.11 \mathrm{~cm}^{3} \mathrm{~g}^{-1}(\operatorname{argF} 1)$. The CEC values of the raw sample $(\operatorname{argB})$ and the separated fine fraction $(\operatorname{argF} 1)$ are $7.3 \mathrm{meq}^{-1}$ and $9.5 \mathrm{meq}^{-1}$ $(\operatorname{argF} 1)$ respectively. These values are low as usually observed for kaolinite (Holtzapffel, 1985; Ma \& Eggleton, 1999).

\section{Infrared and NMR spectroscopies}

The IR spectra of the samples are reported in Fig. 7. The $\mathrm{OH}$ stretching vibration modes of the structural hydroxyl groups occur at 3693, 3665, 3650 and $3620 \mathrm{~cm}^{-1}$. The $3665 \mathrm{~cm}^{-1}$ band is absent in the IR spectrum of $\operatorname{ArgF} 2$. It is known

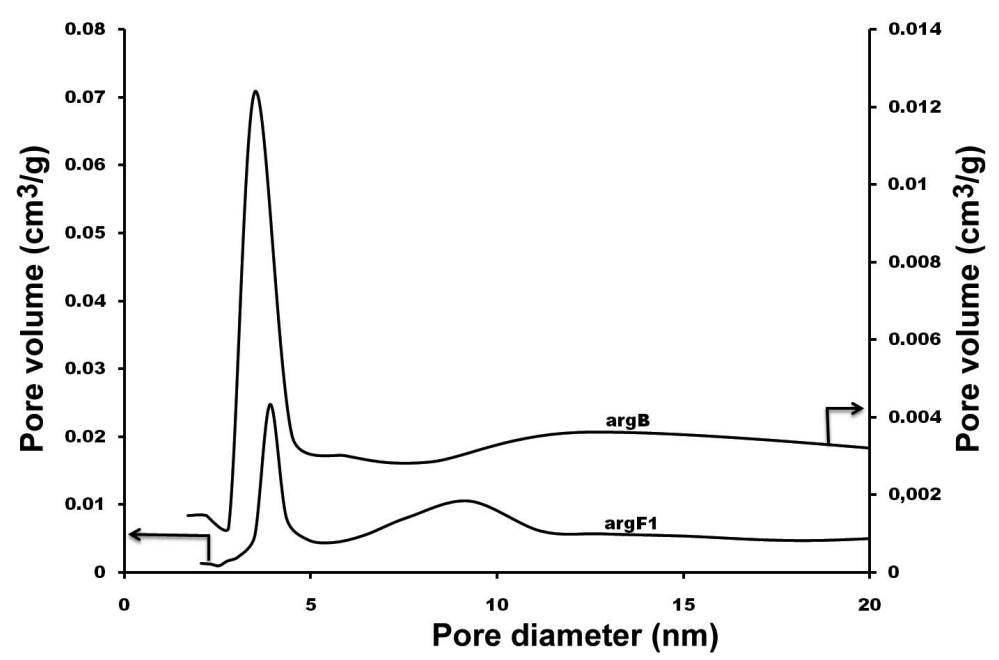

FIG. 6. BJH pore size distribution curve of the raw clay sample $(\operatorname{argB})$ and the Na-separate clay $(\operatorname{argF} 1)$. 


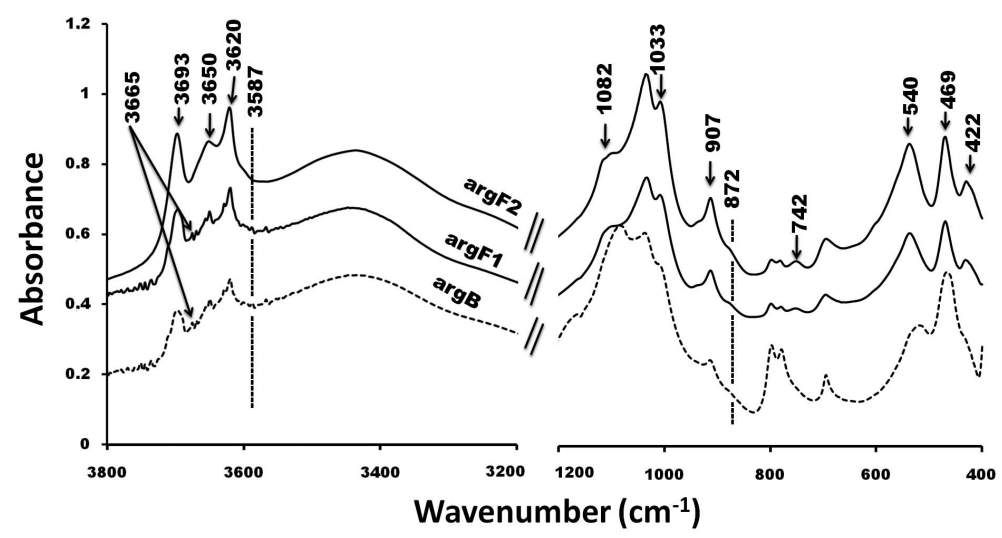

FIG. 7. Infrared spectra of the raw sample $\operatorname{argB}$ and the purified samples $\operatorname{argF} 1 \operatorname{and} \operatorname{argF} 2$.

that kaolinite has a characteristic signature consisting of four bands in the $3700-3600 \mathrm{~cm}^{-1}$ region, one band for internal hydroxyl and three bands for inner-surface hydroxyls. Also, the innersurface hydroxyl stretching bands is known to be influenced by interlayer modifications (Tamer\& Christian, 2008; Petit \& Decarreau, 1990; Farmer, 1974). The band at $3620 \mathrm{~cm}^{-1}$ is attributed to the stretching frequency of the internal (inner) hydroxyl groups of the kaolinite while the two bands at 3693 and $3665 \mathrm{~cm}^{-1}$ are due to in-phase and out-ofphase combination bands. The assignment of the band at $3650 \mathrm{~cm}^{-1}$ is still controversial (Petit et al., 1995). The broad bands around 3440 and 1630 $\mathrm{cm}^{-1}$ are due to the stretching and bending vibration of adsorbed water, respectively.

In the spectra of the three samples, the shoulder at $872 \mathrm{~cm}^{-1}$ is due to $\gamma \mathrm{AlFe}^{3+} \mathrm{OH}$. This peak appears in synthetic kaolinite with another one located at $\sim 3600 \mathrm{~cm}^{-1}$ attributed to $\delta \mathrm{AlFe}^{3+} \mathrm{OH}$ (Petit \& Decarreau, 1990). The former peak is visible in $\operatorname{argF} 1$ that is an iron-rich sample. These two peaks are not visible for natural kaolinite most of the time according to Petit \& Decarreau (1990).

The intense bands around $1033 \mathrm{~cm}^{-1}$ with two shoulders around 1082 and $1006 \mathrm{~cm}^{-1}$ in the ir spectra of the three samples correspond to the stretching vibrations of the Si-O-Si group and those at 694 and $469 \mathrm{~cm}^{-1}$ are due the bending mode of the same group. The band at $907 \mathrm{~cm}^{-1}$, with a shoulder at $938 \mathrm{~cm}^{-1}$, and the one at $540 \mathrm{~cm}^{-1}$ are related to $\mathrm{Al}-\mathrm{OH}$ and $\mathrm{Al}(\mathrm{VI})-\mathrm{O}-\mathrm{Si}$ bending vibrations, respectively (Petit \& Decarreau, 1990; Wilson, 1994; Van der Marel \& Beutelspacher, 1976; Saikia et al., 2003). The presence of quartz in the three samples is confirmed by the bands at 800 and $775 \mathrm{~cm}^{-1}$ (Vizcayno et al., 2010). The intensity of these two peaks decreases considerably in the ir spectra of purified samples ( $\operatorname{argF} 1$ and $\operatorname{argF} 2)$ in comparison with the raw sample ( $\operatorname{argB})$. After purification, the increase in intensity of the bands at 907 and $540 \mathrm{~cm}^{-1}$ and the decrease of those due to quartz at 800 and $775 \mathrm{~cm}^{-1}$ indicate a fine fraction richer in clays than the raw sample, which is in good agreement with the XRD results (Fig. 4) and chemical analysis (Table 1).

29Si and ${ }^{27} \mathrm{Al}$ MAS-NMR spectra of the treated $\mathrm{Na}^{+}$-separated fine fraction $(\operatorname{argF} 2)$ are shown in Fig. 8. The ${ }^{29} \mathrm{Si}$ MAS-NMR spectrum exhibits two main lines at -91.3 and $-107.3 \mathrm{ppm}$. The intense singlet at $-91.3 \mathrm{ppm}$ with a full width at half maximum of about $5 \mathrm{ppm}$ is attributed to a silicon atom linked to three other silicons via an oxygen atom $\left(Q^{3}\right.$ environment) and can be attributed to the presence of kaolinite, in line with previous reports (Rocha \& Klinowski, 1990; Sanz \& Sarrataso, 1984; Plee et al., 1985; Engelhardt \& Michel, 1987). The second chemical shift value found at $-107.3 \mathrm{ppm}$ can be attributed to the presence of quartz (silicon in a $\mathrm{Q}^{4}$ environment) (Janes \& Oldfield, 1985).

The ${ }^{27} \mathrm{Al}$ MAS-NMR spectrum shows an intense peak at $4.4 \mathrm{ppm}$, corresponding to six coordinated $\mathrm{Al}$ atoms. The other relatively symmetrical peaks are attributed to spinning side bands. From the NMR data and following previous work, it can be stipulated that there is a reaction between the iron oxides and the kaolinite as the peak due to ${ }^{27} \mathrm{Al}$ shifted to the positive side compared to $\delta\left({ }^{27} \mathrm{Al}\right)$ in pure kaolinite ( Wei et al., 2012). Isomorphous substitution of $\mathrm{Fe}$ by $\mathrm{Al}$ is very common when iron oxides and kaolinite are mixed. 


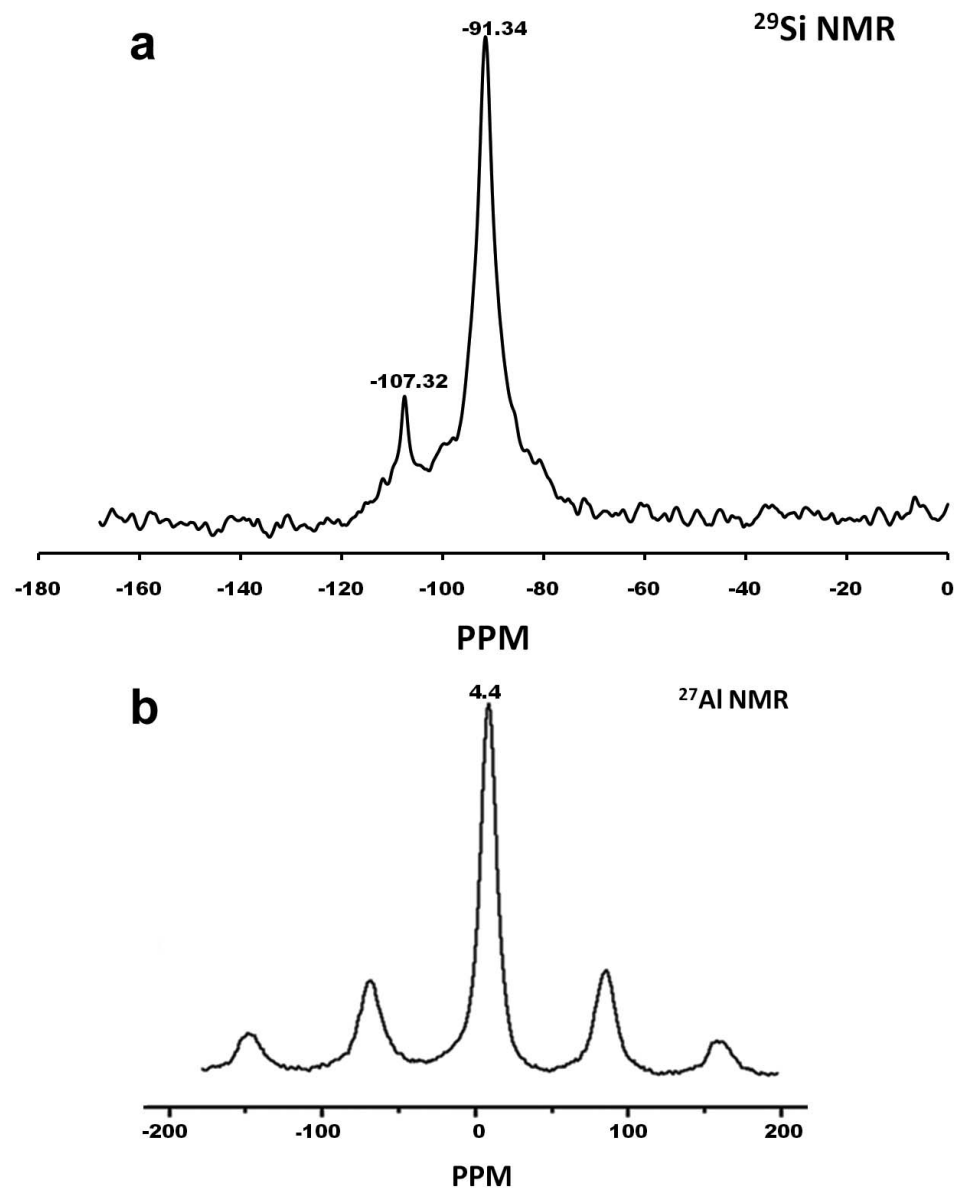

FIG. 8. MAS NMR spectra of the fine fraction sample (argF2): (a) ${ }^{29} \mathrm{Si}$ and (b) ${ }^{27} \mathrm{Al}$ spectra.

\section{Thermal analysis}

TG-DTA thermograms of the raw sample $(\operatorname{argB})$ and the treated Na-saturated separate fraction $(\operatorname{argF} 2)$ are illustrated in Fig. 9. In both cases, a clear endothermic effect is observed between 100 and $200^{\circ} \mathrm{C}$ associated with a weight loss of $\sim 1.7 \%$ for the raw clay $(\operatorname{argB})$ and $4.8 \%$ for the treated Naclay fraction $(\operatorname{argF} 2)$. The two endothermic peaks in sample $\operatorname{argB}$ located at $\sim 73^{\circ} \mathrm{C}$ and $132^{\circ} \mathrm{C}$ are due to the dehydration process. The peak at $132^{\circ} \mathrm{C}$ probably corresponds to the dehydration of divalent ions (Caillère et al., 1982). The same phenomenon is observed for $\operatorname{argF} 2$ at $92^{\circ} \mathrm{C}$ and $146^{\circ} \mathrm{C}$. The presence of the two endothermic peaks at low temperature due to dehydration is consistent with the heterogeneous occupancy of interlayer spaces with various compensating cations (Caillère et al.,
1982); it confirms the result of chemical analysis which showed incomplete saturation of the fine clay mineral fraction by $\mathrm{Na}^{+}$. The dehydroxylation of kaolinite occurs at $470^{\circ} \mathrm{C}$ for the raw clay and $488^{\circ} \mathrm{C}$ for the Na-clay fraction; the corresponding weight loss is $\sim 1.0 \%$ and $6.6 \%$, respectively. At these temperatures, a disordered phase called metakaolinite with a typical chemical formula $\mathrm{Al}_{2} \mathrm{Si}_{2} \mathrm{O}_{7}$ (Vizcayno et al., 2010) is formed. The additional endothermic peak at $573^{\circ} \mathrm{C}$ observed only in the raw clay is due to the transformation of $\alpha$ quartz into $\beta$-quartz. The exothermic peaks observed at 904 and $915^{\circ} \mathrm{C}$ for $\operatorname{argB}$ and $\operatorname{argF} 2$, respectively, correspond to the structural reorganization of metakaolinite into mullite. The transformation of mullite into secondary mullite occurs at $1134^{\circ} \mathrm{C}$ for $\operatorname{argB}$ and at $1150^{\circ} \mathrm{C}$ for $\operatorname{argF} 2$. 


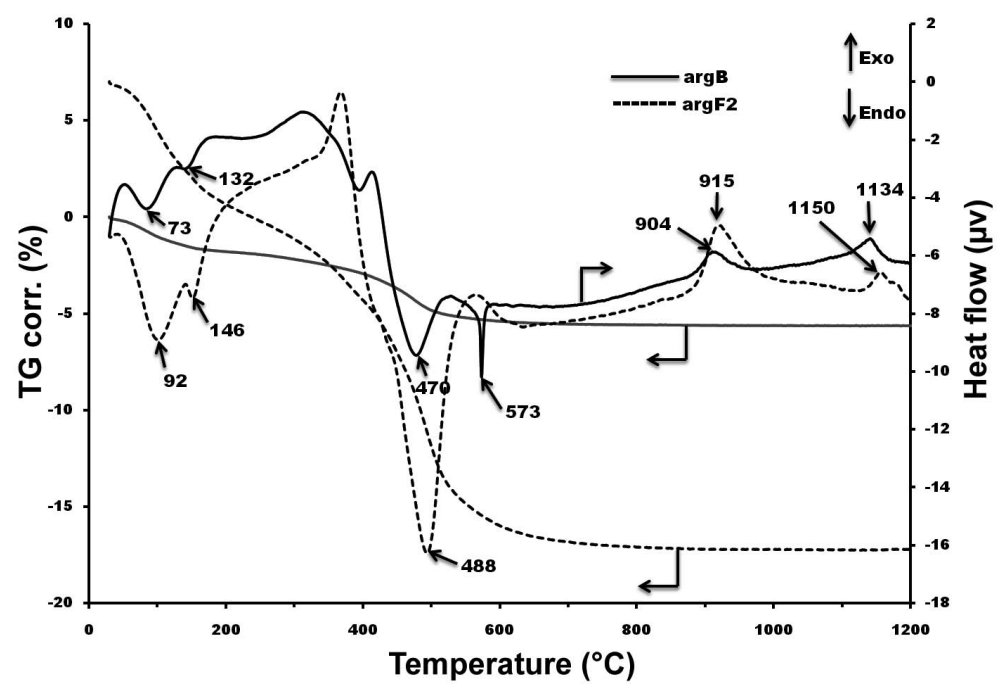

FIG. 9. TGA and DTA spectra of the raw clay sample $(\operatorname{argB})$ and the treated fine clay fraction $(\operatorname{argF} 2)$.

\section{CONCLUSIONS}

Several techniques were used to characterize the raw clay from Keur Saër (Senegal) and its separated fine fraction. The results show that the raw clay is essentially composed of quartz and kaolinite. The fine clay fraction was isolated and its principal composition is predominantly kaolinite with a small amount of quartz. Due to the total or partial removal of diluting minerals (essentially quartz) on purification, the specific surface area was increased by a factor two for the separated fine fraction $\left(73.2 \mathrm{~m}^{2} \mathrm{~g}^{-1}\right)$ compared with the raw clay sample $\left(28.9 \mathrm{~m}^{2} \mathrm{~g}^{-1}\right)$. Subsequently the cationic exchange capacity was also significantly higher, i.e. $9.5 \mathrm{meq} \mathrm{g}^{-1}$ and $7.3 \mathrm{meq} \mathrm{g}^{-1}$, respectively. The $\mathrm{N}_{2}$ adsorption-desorption isotherms of the raw and purified samples belong principally to the type IV with a hysteresis loop of type H3; the contribution of micropores is also noteworthy. The fact that the fine clay fraction in this geographical area is mainly kaolinite confirms that its best use is principally as bricks for building and ceramics for household purposes.

\section{ACKNOWLEDGMENTS}

Partial financial support from the "Programme de Coopération Scientifique Interuniversitaire de l'Agence Universitaire de la Francophonie" ( $\mathrm{N}^{\circ} 63$ 13PS826) is gratefully acknowledged.

\section{REFERENCES}

Bailey S.W. (1980) Structures of layer silicates. In: Brindley G.W \& Brown G (eds) Crystal Structures of Layer Silicates and their X-Ray Identification, pp 1123. Mineralogical Society, London.

Barrusseau J.P., Duvail C., Noel B.J., Nehlig P., Roger J. $\&$ Serrano O. Notice explicative de

la carte géologique du basin sédimentaire du Sénégal, Direction des Mine du Sénégal, 2009.

Bouna L., Rhouta B., Amjoud M., Jada A., Maury F., Daoudi, F. \& Senocq L. (2010) Correlation between eletrokinetic mobility and ionic dyes adsorption of Moroccan stevensite. Applied Clay Science, 48, 527-530.

Bouna L., Rhouta B., Amjoud M., Maury F., Lafont MC., Jada A., Senocq F. \& Daoudi L. (2011) Synthesis, characterization and photocatalytic activity of $\mathrm{TiO}_{2}$ supported natural palygorskite microfibers. Applied Clay Science, 52, 301-311.

Brigand F. (1960) Connaissance du Sénégal, Wagoningen, the Netherlands. Fascicule Géologie Centre IFAN-Sénégal Saint Louis du Sénégal.

Brunauer S., Emmet P.H \& Teller E. (1938) Adsorption of gases in multimolecular layers. Journal of the American Chemical Society, 60, 309-319.

Caillère S., Hénin S. \& Rautureau M. (1982) Minéralogie des Argiles: 1. Structures et Propriétés Physico-Chimiques, 2. Classification et Nomenclature. Masson Paris, 184 pp.

Engelhardt G. \& Michel D. (1987) High Resolution Solid-State NMR of Silicates and Zeolites. John Wiley \& Sons, New York, 485 pp.

Farmer V.C. (1974) The Infrared Spectra of Minerals. Monograph 4, Mineralogical Society, London, 
$331-363$

Grim R.E. (1960) Some applications of clay mineralogy. American Mineralogist, 45, 259-260.

Holtzapffel T. (1985) Les minéraux argileux: préparation, analyse diffractométrique et détermination. Société Géologique du Nord, 12, 1-135.

Jackson M.L. (1975) Soil Chemical Analysis Advanced Course, $2^{\text {nd }}$ edition. Published by the author, Madison, Wisconsin, 895 pp.

Janes N. \& Oldfield E. (1985) Prediction of silicon-29 nuclear magnetic resonance chemical shifts using a group electronegativity approach: applications to silicate and aluminosilicate structures. Journal of the American Chemical Society, 107, 6769-6775.

Lim C.H., Jackson M.L., Koons R.D. \& Helmke P.A. (1980) Kaolins: sources of differences in cationexchange capacities and cesium retention. Clays and Clay Minerals, 28, 223-229.

Ma C. \& Eggleton R.A. (1999) Cation exchange capacity of kaolinite. Clays and Clay Minerals, 47, 174-180.

Mantin I. \& Glaeser R. (1960) Fixation des ions cobalt hexamine par les montmorillonites acides. Bulletin du Groupe Français des Argiles, 50, 83-88.

Marcos F. \& Rosa B.D. (1995) The use of clays for the hydrotreatment of heavy crude oils. Catalysis Reviews, 37, 1-100.

Meunier S. (1898) Contribution à la géologie du BasSénégal. Comptes Rendus Académie des Sciences, 126, 666-669.

Meunier S. (1904) Contribution a la connaissance des formations lutétiennes au Sénégal. Comptes Rendus Académie des Sciences, 138, 62-63.

Moussi B., Medhioub M., Hatira N., Yans J., Hajjaji W., Rocha F., Labrincha J.A. \& Jamoussi F. (2011) Identification and use of white clay deposits from the area of Tamra (northern Tunisia) as ceramic raw materials. Clay Minerals, 46, 165-175.

Ormsby W.C., Shartsis J.M. \& Woodside K.H. (1962) Exchange behavior of kaolins of varying degrees of crystallinity. Journal of the American Ceramic Society. 45 361-365.

Petit S. \& Decarreau A. (1990) Hydrothermal $\left(200^{\circ} \mathrm{C}\right)$ synthesis and crystal chemistry of iron-rich kaolinites. Clay Minerals, 25, 181-196.

Petit S., Decarreau A. Mosser C., Ehret G. \& Grauby O. (1995) Hydrothermal synthesis $\left(250^{\circ} \mathrm{C}\right)$ of coppersubstituted kaolinites. Clay Minerals, 43, 482-494.

Pialy P., Nkoumbou C., Villiéras F., Razafitianamaharavo A., Barres O., Pelletier M., Ollivier G., Bihannic I., Njopwouo D., Yvon J. \& Bonnet J.P. (2008) Characterization for industrial applications of clays from Lembo deposit, Mount Bana (Cameroon). Clay Minerals, 43, 415-435.

Plee D., Borg F., Gatineau L. \& Fripiat J. J. (1985) High-Resolution Solid-State ${ }^{27} \mathrm{Al}$ and ${ }^{19} \mathrm{Si}$ Nuclear Magnetic Resonance Study of Pillared Clays.
Journal of the American Chemical Society, 107, 2362-2369.

Rebelo M., Rocha F. \& Ferreira da Silva E. (2010) Mineralogical and physicochemical characterization of selected Portuguese Mesozoic-Cenozoic muddy/ clay raw materials to be potentially used as healing clays. Clay Minerals, 45, 229-240.

Rhouta B., Kaddami H., Elbarqy, J. Amjoud M'B., Daoudi L., Maury F., Senocq F., Maazouz A. \& Gerard J.-F. (2008) Elucidation of the structure of the Jbel Rhassoul stevensite (Morocco) by advanced physico-chemical study. Clay Minerals, 43, 393-404.

Ribeiro M.J., Albuquerque C.M. \& Labrincha J.A. ( 2008) Removal of $\mathrm{Pb}^{2+}$ and $\mathrm{Ni}^{2+}$ ions from aqueous media by filtration through clay-based beds. Clay Minerals, 43, 647-656.

Ritz M. \& Bellion Y. (1988) Geologic section across the onshore Senegal-Mauritania Basin derived from geoelectric studies. Canadian Journal of Earth Sciences, 26, 65-73.

RochaicasJ. \& Klinowski J. (1990) ${ }^{29} \mathrm{Si}$ and ${ }^{27} \mathrm{Al}$ magicangle-spinning NMR studies of the thermal transformation of kaolinite. Physics and Chemistry of Minerals, 17, 179-186.

Roques M. \& Nickles M. (1946) Sur la situation stratigraphique des quartzites de Bakel (Senegal). Comptes Rendus Académie des Sciences, 222, 1452-1454.

Saikia N.J., Bharali D.J., Sengupta P., Bordoloi D., Goswamee R.L., Saskia P.C. \& Borthakur P.C. (2003) Characterization, beneficiation and utilization of a kaolinite clay from Assam, India. Applied Clay Science, 24, 93-103.

Sanz J. \& Sarrotaso J.M. (1984) ${ }^{29} \mathrm{Si}$ and ${ }^{27} \mathrm{Al}$ highresolution MAS-NMR spectra of phyllosicates. Journal of the American Chemical Society, 106, 4790-4793.

Sayin A.S. (2007) Origin of kaolin deposits: Evidence from the Hisarcik (Emet-Kutahya) deposits, Western Turkey. Turkish Journal of Earth Sciences, 16, 7796.

Sing K.S.W., Everett D.H., Haul R.A.W., Moscou L., Pierotti R., Rouquerol J. \& Siemienwska T. (1985) Reporting physisorption data for gas/solid systems with special reference to the determination of surface area and porosity Pure and Applied Chemistry, 57 $603-619$.

Suarez B.M., Flotes G. L.V., Vicente R.M.A \& Martin P.J.M. (1995) Acid activation of palygorskite with HCL development of physico-chemical, textural and surface properties. Applied Clay Science, 10, $247-258$.

Tamer A. E. \& Christian D. (2008) Intercalation of cyclic imides in kaolinite, Journal of Colloid and Interface Science, 323, 338-348.

Tessier F. (1946) Sur l'existence d'un niveau maes- 
trichtien au Sénégal. Comptes Rendus Académie des Sciences, 222, 505-506.

Tessier F. (1949) Le Paléocène au Sénégal. Comptes Rendus Sociétés Géologiques de France. 11, 227-229.

Van der Marel H.W. \& Beutelspacher S. (1976) Atlas of Infrared Spectroscopy of Clay Minerals and their Admixtures. Elsevier, Amsterdam, 397 pp.

Vizcayno C. Gutiérrez R. M., Castello R., Rodriguez E. \& Guerrero C.E. (2010) Pozzolan obtained by mechanochemical and thermal treatments of kaolin. Applied Clay Science, 49, 405-413.

Wilson M.J. (1994) Clay Mineralogy: Spectroscopic and Chemical Determinative Methods. Chapman and
Hall, 18-21.

Wyszomirski P. \& Galos K. (2009) Polish clay raw materials for the production of ceramic tiles. Clay Minerals, 44, 497-509.

Wei S., Tan W., Zhao W. Fan Liu Y.T.Y. \& Koopal L.K. (2012) Microstructure, interaction mechanisms and stability of binary systems containing goethite and kaolinite. Soil Science Society of America Journal, 76, 389-398.

Zheng S.Q., Han Y., Huang X.H., Dai Y.L., Qian D., Zhang J.C. \& Ren S. (2010) Acid and aluminum modification of sepiolite and its application in FCC catalysis. Clay Minerals, 45, 15-22. 